\title{
Effect of Synthetic and Organic Soil Fertility Amendments on Southern Blight, Soil Microbial Communities, and Yield of Processing Tomatoes
}

\author{
L. R. Bulluck III and J. B. Ristaino
}

Department of Plant Pathology, North Carolina State University, Raleigh 27695.

Current address of L. R. Bulluck III: Visiting Postdoctoral Scholar, Department of Plant Pathology, University of California, Davis 95616. Accepted for publication 31 October 2001.

\begin{abstract}
Bulluck, L. R., III, and Ristaino, J. B. 2002. Effect of synthetic and organic soil fertility amendments on southern blight, soil microbial communities, and yield of processing tomatoes. Phytopathology 92:181189.

Soil fertility amendments, including composted cotton-gin trash, swine manure, a rye-vetch green manure, or synthetic fertilizers, were applied to subplots and tillage on bare soil; or tillage followed by surface mulch with wheat straw were applied to main plots to determine the effect on the incidence of southern blight caused by Sclerotium rolfsii, yield of processing tomato, and soil microbial communities. The amendmenttillage interaction was significant in 1997 and disease incidence was 67\% in tilled bare soil receiving synthetic fertilizers; whereas disease incidence was 3,12 , and $16 \%$ in surface-mulched plots amended with a com-

plots receiving cotton-gin trash, swine manure, or rye-vetch green manure, respectively. In 1997, yields were highest in tilled surface-mulched plots amended with synthetic fertilizers, cotton-gin trash, or swine manure, respectively. In 1998, yields were low in all plots and there were no significant differences in yield due to treatment. Propagule densities of antagonistic soil fungi in the genus Trichoderma were highest in soils amended with composted cotton-gin trash or swine manure in both years. Propagule densities of fluorescent pseudomonads in soil were higher in plots amended with organic amendments than with synthetic fertilizers in both years. Propagules densities of enteric bacteria were elevated in soils amended with raw swine manure biosolids in both years. Our research indicates that some organic amendments, such as cotton-gin trash, reduced the incidence of southern blight in processing tomato and also enhanced populations of beneficial soil microbes.
\end{abstract} posted cotton-gin trash, swine manure, or a rye-vetch green manure. The amendment effect was significant in 1998, and disease incidence was $61 \%$ in plots receiving synthetic fertilizer and was 23,44 , and $53 \%$ in
Additional keywords: organic agriculture, sustainable agriculture.

29,30). Solarization in combination with application of biocontrol agents has also been effective in reducing disease (39).

Many of the sandy coastal plain soils in eastern North Carolina used for vegetable production are low in organic matter and the use of composted animal wastes or plant-derived composts and mulches could increase the organic matter content of the soil (13). Confined animal production has expanded tremendously over the last decade in eastern North Carolina, and the animal waste generated by these facilities has also increased. Environmental concerns, including overflow of liquid effluent from hog lagoons and fish kills in nearby rivers, has led scientists and growers to seek alternative uses for the animal wastes $(9,23)$.

Animal wastes provide an important under-utilized source of organic nutrients for plants and could be used to suppress plant disease (21). There are several previous reports that have demonstrated that composted animal and plant wastes can suppress diseases caused by soilborne pathogens, including $S$. rolfsii $(10,20)$. Composts have been used in potting media to suppress soilborne pathogens $(19,20)$. Organic amendments have also been used in the field to control Rhizoctonia on cauliflower (22), Fusarium yellows on bean (27), and Phytophthora cinnamomi Rands in avocado plantations (45). Lower incidences of corky root caused by Pyrenochaeta lycopersici R. Schneider \& Gerlach were found in California tomato fields under organic production than in fields under conventional production (14).

Limited work has been done to evaluate organic amendments for control of southern blight in the field (10). The objective of this research was to compare the effect of synthetic versus organic soil fertility amendments and tillage practices on the incidence of southern blight, the population dynamics of selected soil microbial 
communities, and yield of processing tomato. An abstract of a portion of this work has been reported previously (8).

\section{MATERIALS AND METHODS}

Research was conducted at the Horticultural Crops Research Station (HCRS) in Clinton, NC in 1997 and 1998. The soil at HCRS is an Orangeburg sandy loam soil (77\% sand, $17 \%$ silt, and $6 \%$ clay, $\mathrm{pH} 5.6,<0.5 \%$ organic matter). The entire field was artificially infested with sclerotia of $S$. rolfsii and a bran-prill formulation of the antagonistic fungus $G$. virens in 1988-90 (38). Propagule densities of $S$. rolfsii were not quantified initially in the soil, but the field had a history of disease, so additional inoculum of $S$. rolfsii was not added.

Composted cotton-gin trash (CGT) was obtained from Cotton Ginning and Sales in Goldsboro, NC. The material (consisting of cotton bolls, stems, seeds, and fiber from cotton) was mixed with small amounts of soil at least twice during the period of composting. CGT contained an average of $0.12 \%$ plant-available nitrogen, $0.24 \%$ phosphorus, and $0.60 \%$ potassium (dry weight). CGT also contained other nutrients, including $1.66 \%$ calcium, $0.33 \%$ magnesium, and $0.28 \%$ iron (dry weight basis).

Swine manure waste was obtained from a swine waste treatment system installed at the Center for Environmental Farming Systems in Goldsboro, NC. Swine waste biosolids consisted of feces, hair, and corn meal-soy meal feed and were not composted. The solid waste from the swine house was screened through a 1.6-mm wire-mesh screen, placed in a manure spreader, and stored usually for less than a week prior to field application. We used raw biosolids because composted swine manure was unavailable in NC at the time the research was conducted. Swine waste biosolids contained an average of $0.34 \%$ plant-available nitrogen, $0.12 \%$ available phosphorus, and $0.14 \%$ potassium on a wet weight basis (15\% dry matter). Calcium $(0.56 \%)$, magnesium $(0.12 \%)$, and iron $(0.05 \%)$ (wet weight basis) also were present in the swine manure.

Synthetic fertilizers for this experiment were obtained from Royster-Clark (Tarboro, NC) and consisted of a 10-10-10 formulation of $\mathrm{NH}_{3} \mathrm{NO}_{3}$ (10\% plant-available nitrogen), $\mathrm{P}_{2} \mathrm{O}_{5}$ (10\% plantavailable phosphorus), and $\mathrm{K}_{2} \mathrm{O}$ (10\% plant-available potassium).

Field plot design. The experimental design was a randomized split plot with four replicates of each treatment. Either tillage on bare soil or tillage followed by surface mulch with wheat straw was applied to the two main plots, and either synthetic fertilizer, CGT, raw swine manure biosolids, or an incorporated rye-vetch green manure were applied to the four subplot treatments. The same main plot (tillage and surface mulch or tillage and bare soil) and subplot (soil fertility amendments) treatments were applied to the same individual plots in both 1997 and 1998. Rates of each soil amendment were standardized to obtain approximately $112 \mathrm{~kg}$ of plant-available nitrogen per hectare. Each experimental unit consisted of six amended rows that were $7.6 \mathrm{~m}$ long and $1.6 \mathrm{~m}$ wide. Data were collected from the internal four rows of the six-row plots.

Granulated dolomite lime was applied once over the entire field in September 1996 at a rate of $2,511 \mathrm{~kg} / \mathrm{ha}$ to obtain a soil $\mathrm{pH}$ of $\approx 6.2$. In the fall of 1996 and 1997, a rye-vetch cover crop was planted at a rate of winter rye at $56 \mathrm{~kg} / \mathrm{ha}$ and hairy vetch at $28 \mathrm{~kg} / \mathrm{ha}$. Subplot soils were amended 2 weeks prior to planting with either synthetic fertilizer (67 kg of NPK/ha, wet weight), CGT (83 t/ha, wet weight), swine manure (32.9 t/ha, wet weight), or the rye-vetch cover crop (flail mowed and incorporated) in the spring of 1997 and 1998. Incorporation of amendments to $30 \mathrm{~cm}$ was conducted with a Ferguson Tillovator and a 1.6-m bed shaper on 14 May 1997 and 28 May 1998. The control subplots that were amended with synthetic fertilizers received additional NPK at $45 \mathrm{~kg} / \mathrm{ha}$ at first flower cluster.

Seed of the processing tomato cv. Rio Colorado were planted in 200-cell flats containing Metro Mix (W. R. Grace and Co., Cambridge, MA) and fertilized biweekly with Peter's Fertilizer (10-1010; W. R. Grace and Co.). Six-week-old seedlings were transplanted 14 days after soil amendment into single-row beds (six per experimental unit) and within-row spacing was $30 \mathrm{~cm}$. Overhead irrigation was utilized as needed ( 2.5 to $3 \mathrm{~cm}$ per week). Tomato seedlings were transplanted on 2 June 1997 and 11 June 1998.

Weeds were tilled with layby cultivation once in both years in all plots prior to surface mulch application. Those main plots that received tillage were then tilled monthly until tomato plants were too large for a tractor to clear (approximately 2 months after transplanting). Wheat straw was applied to a thickness of 5 to $7 \mathrm{~cm}$ to surface-mulched main plots $\approx 2$ to 3 weeks after transplanting, immediately after the single layby tillage was applied.

Disease incidence and tomato yield. The incidence of southern blight in the interior four rows of each six-row experimental unit was monitored weekly until harvest in both years. Plants were

TABLE 1. Media, dilution factors, organisms, and incubation conditions for microorganisms isolated from soils in plots amended with synthetic and organic fertility amendments

\begin{tabular}{|c|c|c|c|c|c|c|}
\hline Medium & Dilution factor $^{\mathrm{a}}$ & Organisms cultured & Temperature $\left({ }^{\circ} \mathrm{C}\right)$ & Incubation (days) & Light conditions & Reference \\
\hline Masago's ${ }^{b}$ & $10^{-1}, 10^{-2}$ & Pythium and Phytophthora spp. & 22 & $5-7$ & Dark & 24 \\
\hline Trichoderma Medium E & $10^{-2}, 10^{-3}$ & Trichoderma spp. & 22 & 7 & Light & 31 \\
\hline Yeast glucose agar & $10^{-2}, 10^{-3}$ & Thermophilic microorganisms & 45 & $2-4$ & Dark & 44 \\
\hline GYRBA & $10^{-3}$ & Fusarium spp. & 22 & $5-7$ & Dark & 28 \\
\hline King's medium B & $10^{-4}, 10^{-5}$ & Fluorescent Pseudomonas spp. & $20-25$ & $5-7$ & Dark & 41 \\
\hline Endo & $10^{-5}, 10^{-6}$ & Enteric bacteria & 37 & $1-2$ & Dark & 11 \\
\hline $\mathrm{PDA}^{\mathrm{c}}$ & $10^{-4}, 10^{-5}$ & Culturable fungi & $20-25$ & $3-5$ & Dark & 45 \\
\hline $\mathrm{TSA}^{\mathrm{d}}$ & $10^{-6}, 10^{-7}$ & Culturable bacteria & $20-25$ & $1-2$ & Dark & 11 \\
\hline
\end{tabular}

a Dilutions were 10 -fold serial dilutions in $0.25 \%$ water agar.

b Masago's media was prepared without hymexazol.

c $\mathrm{PDA}=$ potato dextrose agar amended with streptomycin sulfate at $100 \mu \mathrm{g} / \mathrm{ml}$ to inhibit bacterial growth.

d TSA = tryptic soy agar amended with Nystatin (Sigma-Aldrich, St. Louis) at $100 \mu \mathrm{g} / \mathrm{ml}$ to inhibit fungal growth.

TABLE 2. Average monthly temperatures, total monthly precipitation, and 30-year averages at the Horticultural Crops Research Station, Clinton, NC

\begin{tabular}{|c|c|c|c|c|c|c|}
\hline \multirow[b]{2}{*}{ Month } & \multicolumn{3}{|c|}{ Average temperature $\left({ }^{\circ} \mathrm{C}\right)^{\mathrm{a}}$} & \multicolumn{3}{|c|}{ Precipitation $(\mathrm{cm})$} \\
\hline & 1997 & 1998 & 30 -year average & 1997 & 1998 & 30-year average \\
\hline June & 23.00 & 26.28 & 23.61 & 3.48 & 4.67 & 10.31 \\
\hline July & 27.06 & 27.72 & 25.78 & 24.94 & 6.15 & 12.67 \\
\hline
\end{tabular}

a Data from the National Climatic Data Center, Climatological Data Annual Summary 1997, vol. 102, and 1998, vol. 103. 
rated as diseased if visible brown lesions or sclerotia were observed near the crown of the plant or on any portion of the stem. Disease symptoms began 40 days after transplanting in 1997 (12 July 1997) and 7 days after transplanting in 1998 (18 June 1998). Tomato were harvested from the interior four rows, and yields were obtained 72 days after transplanting in 1997 and 74 days after transplanting in 1998.

Soil microbial communities. Six soil cores $(\approx 20 \mathrm{~cm}$ deep and $1.9 \mathrm{~cm}$ wide) were removed from each of the four interior rows of the six-row plots and bulked in a composite sample and mixed. Samples were taken in the plant row, within the root zones. Soil samples were removed from plots 2 weeks after planting (16 June 1997 and 25 June 1998), and at harvest (19 August 1997 and 24 August 1998). Soil samples were placed in coolers with ice and put in cold storage at $5^{\circ} \mathrm{C}$ on the same day. All soil dilutions were done within 2 weeks of soil sampling.

Soil samples were analyzed for microbial population densities using 10-fold serial dilutions of soil and eight selective media (Table 1). Numbers of culturable bacteria, fungi, thermophilic microorganisms, fluorescent pseudomonad bacteria, enteric bacteria, Trichoderma spp., Fusarium spp., Phytophthora and Pythium spp., and sclerotia of $S$. rolfsii were quantified. Serial soil dilutions were conducted by placing $10 \mathrm{~g}$ of soil in $90 \mathrm{ml}\left(10^{-1}\right.$ dilution) of sterile $0.25 \%$ Bacto water agar (Difco Laboratories, Detroit). Serial soil dilutions were done to a dilution of $10^{-7}$ for selected microorganisms (Table 1). Triplicate plates for each medium were used for each sample, and several media were bracketed at different soil dilutions for accurate population estimation. Sclerotia of $S$. rolfsii were enumerated after spreading $100 \mathrm{~cm}^{3}$ of soil in aluminum baking pans and misting the soil with $1 \%$ methanol (40). Colonies were enumerated from plates containing 30 to 300 colonies.

Sclerotia survival in soil. In the second year of the study (July 1998), after tomato plants were established, a test was done to determine if sclerotia germination was suppressed in the plots. Sclerotia of $S$. rolfsii were produced on potato dextrose agar media and air dried. Twenty-five sclerotia were placed in $100 \mathrm{cc}$ of soil obtained from each treatment and replication combination. The infested soil was placed in nylon bags and secured. Three bags were prepared for each experimental unit so that samples at 0,2 , and 4 weeks could be assayed. Two of the three infested soil bags were buried $15 \mathrm{~cm}$ deep on the south side of rows three and four between plants number 12 and 13 in each treatment and replication combination. The third bag of infested soil was used for the 0 time assay. The samples were returned to campus and stored at $4^{\circ} \mathrm{C}$ until the following day. The infested soil was spread in aluminum baking pans and misted with $1 \%$ methanol (40). Number of germinating sclerotia was counted. The sclerotia-infested soil bags were removed from the remaining plots on 17 and 31 July 1998 ( 2 and 4 weeks after placement, respectively), and assayed as described above for sclerotia germination.

Statistical analysis. Data were analyzed using Statistical Analysis Systems software (PC-SAS 7.0 and 8.0; SAS Institute, Cary, NC). The generalized linear model procedure (Proc GLM), and analysis of variance (ANOVA) were performed for microbial population data, tomato yield, and final disease incidence for 1997 and 1998. Area under the disease progress curve (AUDPC) was calculated for disease data collected over time. Variance in microbial count data was normalized using $\log _{10}(x+1)$ transformation, where $x$ equals the average number of propagules per gram of dry soil. Only data with significant $F$ values $(P \leq 0.05)$ are presented.

Rainfall, temperature, and soil physical and chemical analysis. Weather data, including rainfall and temperature data, were obtained from weather station records from the National Climatic Data Center Annual Summaries for June, July, and August 1997 and 1998 and compared with the 30-year averages from the HCRS, Clinton, NC (Table 2).

Soil chemical parameters were measured on subsamples of the same samples used for the microbial assays to determine if the treatments had an impact on soil chemical parameters. Soil chemical parameters, including Mehlich I-extractable $\mathrm{P}, \mathrm{K}, \mathrm{Ca}, \mathrm{Mg}, \mathrm{Mn}$, $\mathrm{Zn}, \mathrm{Cu}$, and $\mathrm{B}$; $\mathrm{pH}$; total Kjeldahl $\mathrm{N} ; \mathrm{NH}_{4}-\mathrm{N} ; \mathrm{NO}_{3}-\mathrm{N}$ (12) were measured at the North Carolina Department of Agriculture soil testing facility. Soil chemical data from the final measurements at the end of year two are shown.

Soil physical parameters, including bulk density and volumetric water release, were measured on soils from each treatment at the end of the second year of the study. Soil bulk density was determined gravimetrically with soil removed with a core sampler of known volume. Bulk soil from each replicated treatment was dried at $80^{\circ} \mathrm{C}$, sieved through a $450-\mu \mathrm{m}$ mesh sieve (U.S. standard 40 ), and $100 \mathrm{~cm}^{3}$ of soil was placed on the fritted glass plate of a 150-ml Büchner funnel of medium porosity (Pyrex No. 36060; Fisher, Pittsburgh, PA). The height of the water column was adjusted to the desired soil water matric potentials $\left(\psi_{\mathrm{m}}\right)$ of $0,-1.0$, $-2.5,-5$, and $-10 \mathrm{KPa}$. Soils were allowed to equilibrate at each $\psi_{\mathrm{m}}$ for $2 \mathrm{~h}$, and a subsample was removed, immediately weighed, and placed in a drying oven at $80^{\circ} \mathrm{C}$ for $24 \mathrm{~h}$ to determine water content (16). Soil water content was plotted as a function of $\psi_{\mathrm{m}}$.

\section{RESULTS}

Incidence of southern blight. Tillage and soil amendments had a significant effect on the final incidence of southern blight and AUDPC in 1997 (Fig. 1A; Table 3). Final disease incidence in
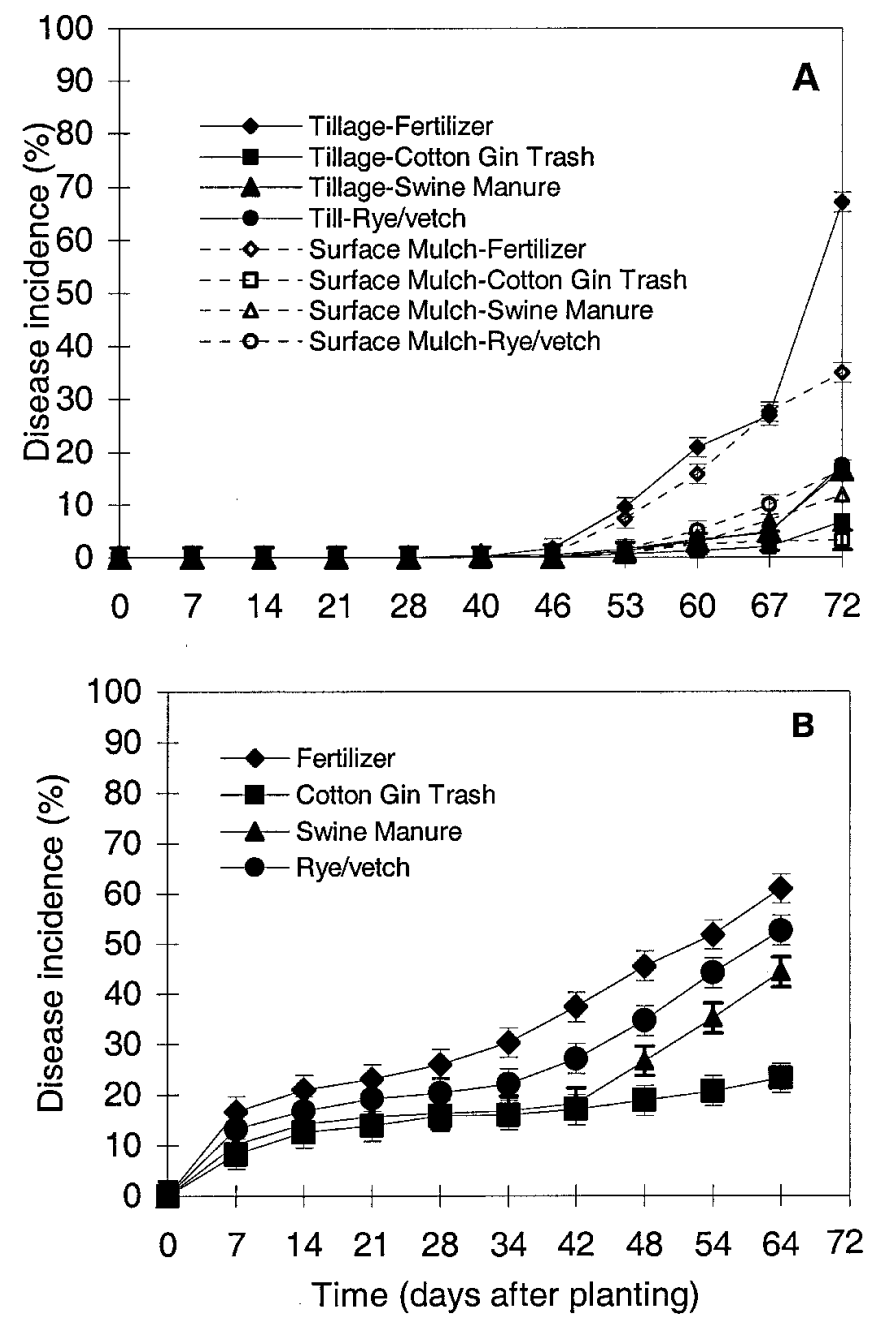

Fig. 1. Incidence of southern blight caused by Sclerotium rolfsii on processing tomatoes at the Horticultural Crops Research Station, Clinton, NC, in A, 1997 and B, 1998 (least significant difference $=1.85$ and $7.78 \%$ ). 
1997 was $67 \%$ in tilled bare-soil plots receiving synthetic fertilizers, and was $6.8,16.5$, and $17.5 \%$ in tilled bare-soil plots that were amended with CGT, swine manure, or rye-vetch, respectively (Fig. 1; Table 3). Final disease incidence in tilled plots that were surface mulched and amended with either synthetic fertilizer, CGT, swine manure, or rye-vetch was $35,3.3,11.8$, and $16.5 \%$, respectively (Table 3, Fig. 1A). The greatest AUDPC and rates of disease progress were in plots amended with synthetic fertilizer, while AUDPCs and rates of disease progress were lower in plots receiving organic amendments (Table 3 ).

Disease onset occurred earlier in 1998 than in 1997 in all plots and was significantly affected by soil amendment (subplots) (Fig. 1B; Table 4). Final disease incidence was $61.0 \%$ in plots amended with synthetic fertilizer and 23.2, 44.3, and 52.6\% in plots amended with CGT, swine manure, and rye-vetch, respectively (Table 4; Fig. 1B). Final disease incidence and AUDPC were significantly greater in soils amended with organic amendments in 1998 than in $1997(P=0.02)$, whereas final disease incidence in tilled soils amended with synthetic fertilizers was similar between years (Tables 3 and 4).

Yield. Soil amendment and tillage had a significant effect on tomato yields in 1997, but only soil amendment significantly affected yield in 1998 (Tables 3 and 4). Yields in 1997 were lower in tilled soils amended with synthetic fertilizer or rye-vetch than tilled soils amended with CGT or swine manure (Table 3). Overall yield of processing tomato was higher in surface-mulched plots than tilled bare-soil plots in 1997. Highest yields were in surfacemulched plots amended with synthetic fertilizers, CGT, or swine manure in 1997, whereas yields were lowest in plots amended with rye-vetch green manure (Table 3). Overall, tomato yields were substantially lower in 1998 than 1997 (Table 4). Rainfall was lower in July 1998 than in July 1997 (Table 1) and this lower rainfall may have affected fruit set. In both years, yields were lowest in plots amended with rye-vetch green manure. In 1998, yields did not differ between plants in plots with the organic and synthetic soil fertility amendments (Table 4).

Soil microbial communities. Soil fertility amendments affected propagule densities of Trichoderma spp. in 1997, whereas the interaction of amendment and time was significant in 1998 (Table 5). Initially, propagule densities of Trichoderma spp. were higher in soils amended with swine manure and CGT than in soils amended with rye-vetch or synthetic fertilizer in 1997 (Fig. 2A). Propagule densities of the Trichoderma spp. increased over time in soils amended with synthetic fertilizers, swine manure, and ryevetch in 1998 (Fig. 2B). Highest propagule densities occurred at harvest in soils amended with CGT or swine manure (Fig. 2B).

Propagule densities of fluorescent Pseudomonas spp. were affected by amendment and time in 1997 and amendment in 1998.

TABLE 3. Effects of tillage and soil amendment on the final disease incidence, area under the disease progress curve (AUDPC), rate of disease progress, and yield of processing tomato at Horticultural Crops Research Station, Clinton, NC, for 1997

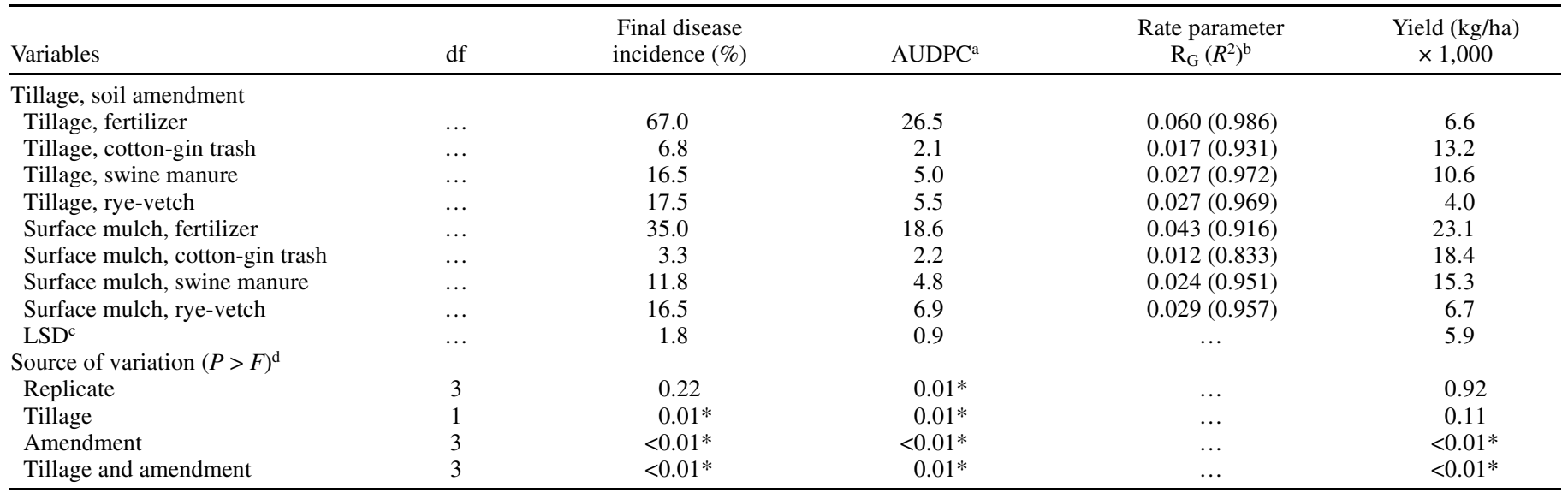

a AUDPC in units of percent-days per day.

b The Gompertz model best described the data and accounted for the most variability. The rate parameter $\mathrm{R}_{\mathrm{G}}$ for the Gompertz model and the $R^{2}$ value for fit of the model to the data are shown.

${ }^{\mathrm{c}}$ Least significant difference from $95 \%$ confidence limits in Mixed procedure (PC SAS 8.0).

d Analysis of variance of all data collected in 1997 using Proc GLM (PC SAS). * Indicates $P>F$ values significant at 0.05 level or less.

TABLE 4. Effects of tillage and soil amendment on the final disease incidence, area under the disease progress curve (AUDPC), rate of disease progress, and yield of processing tomato at Horticultural Crops Research Station, Clinton, NC, for 1998

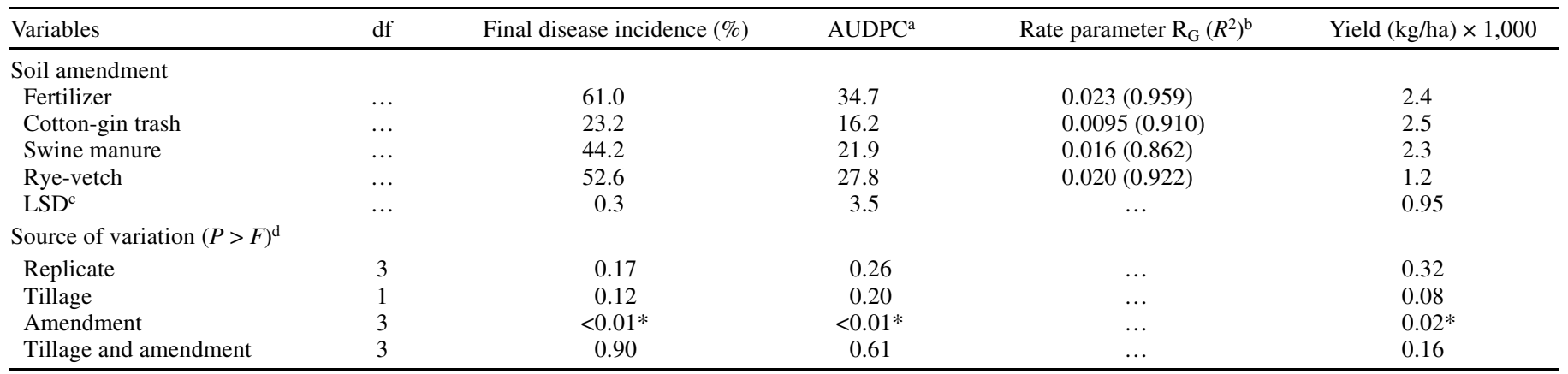

a AUDPC in units of percent-days per day.

${ }^{\mathrm{b}}$ The Gompertz model best described the data and accounted for the most variability. The rate parameter $\mathrm{R}_{\mathrm{G}}$ for the Gompertz model and the $R^{2}$ value for fit of the model to the data are shown.

${ }^{c}$ Least significant difference from $95 \%$ confidence limits in Mixed procedure (PC SAS 8.0).

d Analysis of variance of all data collected in 1997 using Proc GLM (PC SAS). * Indicates $P>F$ values significant at 0.05 level or less. 
Propagule densities of fluorescent Pseudomonas spp. were lower initially in soils amended with synthetic fertilizer at planting than in soil in other plots in 1997 (Fig. 3A). Numbers of these bacteria increased over time in all plots regardless of treatment (Fig. 3A). In 1998, propagule densities of fluorescent Pseudomonas spp. were significantly higher in soils amended with CGT, swine manure, or rye-vetch than with synthetic fertilizer (Fig. 3B). Comparisons of propagule densities of fluorescent pseudomonad species from 1997 and 1998 indicate that these bacteria were one to two orders of magnitude higher in 1998 than in 1997 at planting $(P<0.01)$, at harvest $(P<0.01)$, and over years $(P<0.01)$.

Fusarium spp. were affected by soil amendment and time in 1997 and soil amendment in 1998 (Table 5; Fig. 4A). Propagule densities of Fusarium spp. were initially higher after planting in 1997 in soils amended with swine manure (Fig. 4A), while lowest propagule densities of Fusarium spp. were observed after planting in soils amended with synthetic fertilizer or rye-vetch. Propagule densities of Fusarium spp. decreased with time in soils amended with swine manure and were higher at harvest in soils amended with synthetic fertilizer than in soils amended with rye-vetch green manure, swine manure, or CGT. Similarly, in 1998, propagule densities of Fusarium spp. also were affected by soil amendment, and were higher in soils amended with synthetic fertilizer than CGT, swine manure, or rye-vetch (Fig. 4B).

Propagule densities of culturable bacteria were higher in soils amended with CGT or swine manure than in soils amended with synthetic fertilizer or rye-vetch in both years (Table 5; Fig. 5A and B). Propagule densities of culturable bacteria were lowest in both years in soils amended with synthetic fertilizers. Tillage practices did not affect propagules densities of culturable bacteria.

Propagule densities of enteric bacteria were affected by amendment and time in 1997 and amendment in 1998. Propagule densities of enteric bacteria were higher at planting in soils amended with swine manure biosolids than soils amended with CGT, ryevetch, or synthetic fertilizer in 1997 (Table 5; Fig. 6A). However, propagule densities of enteric bacteria decreased with time in plots amended with swine manure and were not different than in plots with synthetic fertilizer at harvest in 1997. Soils amended with swine manure in 1998 also had higher numbers of enteric bacteria than soils amended with CGT, rye-vetch, or synthetic fertilizers, but the numbers of enteric bacteria did not decrease with time in these plots in the second year (Table 5; Fig. 6B). Overall, propagule densities of enteric bacteria were higher in 1998 than $1997(P<0.01)$.

Propagule densities of other microbial species including total culturable fungi, thermophilic microorganisms, Phytophthora and Pythium spp., and numbers of sclerotia were not significantly affected by treatments over the course of the experiment; therefore, data are not shown.

$S$. rolfsii inoculum germination. Germination of sclerotia of $S$. rolfsii was affected by soil fertility amendments (Table 6). The percent germination of sclerotia was higher over time in soils amended with synthetic fertilizers than in soils with organic fertility amendments (Table 6). The percentage of sclerotia germinating increased in soils amended with synthetic fertilizers over time, but decreased in soils amended with CGT or swine manure. Percent germination of sclerotia changed little over time in soils
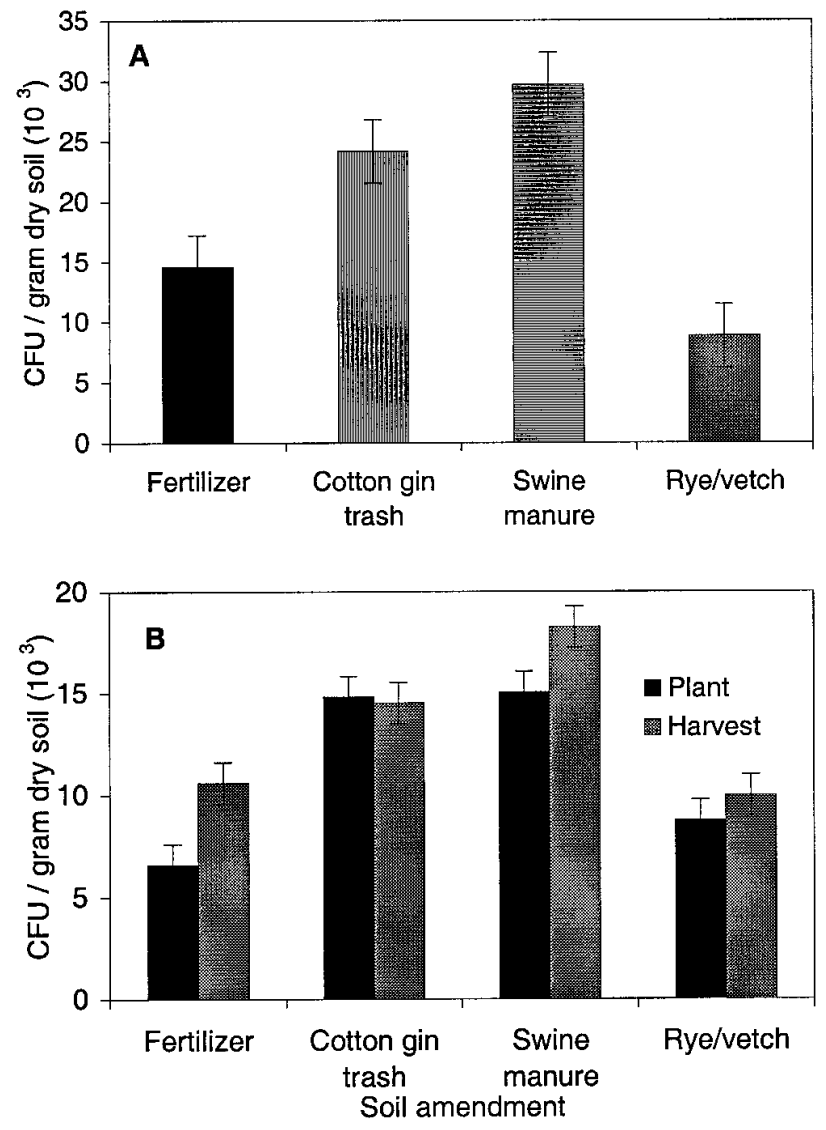

Fig. 2. Propagule densities of Trichoderma spp. (CFU per gram of soil) as affected by A, soil amendments in 1997 or by B, soil amendments and sampling time in 1998 (least significant difference $=2.63 \times 10^{3}$ and $1.02 \times$ $10^{3} \mathrm{CFU} / \mathrm{g}$ of soil in 1997 and 1998, respectively).

TABLE 5. Sources of variation, degrees of freedom, and probability values for propagules densities in soil of select microbial species at Horticultural Crops Research Station, Clinton, NC, 1997 and 1998 ${ }^{\mathrm{a}}$

\begin{tabular}{|c|c|c|c|c|c|c|}
\hline \multirow[b]{2}{*}{ Treatment } & \multirow[b]{2}{*}{ df } & \multicolumn{5}{|c|}{$P>F$} \\
\hline & & Trichoderma spp. & Fluorescent Pseudomonas spp. & Fusarium spp. & Culturable bacteria & Enteric bacteria \\
\hline \multicolumn{7}{|l|}{1997} \\
\hline Tillage $\times$ amendment & 3 & 0.65 & 0.46 & 0.19 & 0.41 & 0.51 \\
\hline Tillage $\times$ time & 1 & 0.34 & 0.32 & 0.32 & 0.71 & 0.17 \\
\hline Amendment $\times$ time & 3 & 0.22 & $0.01 *$ & $<0.01 *$ & 0.61 & $<0.01$ \\
\hline Tillage & 1 & 0.47 & 0.48 & 0.16 & 0.25 & 0.09 \\
\hline Amendment & 3 & $<0.01 *$ & $<0.01 *$ & $<0.01 *$ & $<0.01 *$ & 0.02 \\
\hline Tillage $\times$ amendment & 3 & 0.71 & 0.48 & 0.12 & 0.99 & 0.57 \\
\hline Tillage $\times$ time & 1 & 0.86 & $0.04 *$ & 0.08 & 0.49 & 0.61 \\
\hline Amendment $\times$ time & 3 & $0.03 *$ & 0.22 & 0.13 & 0.07 & 0.32 \\
\hline Tillage $\times$ amendment $\times$ time & 3 & 0.321 & 0.09 & 0.88 & 0.85 & 0.49 \\
\hline
\end{tabular}

a Probabilities greater than $F$ from split-plot analysis of variance using Proc GLM in SAS for populations of Trichoderma spp., Fusarium spp., fluorescent pseudomonads, enteric bacteria, and culturable bacteria for 1997 and 1998; * indicates $P>F$ values were significant at 0.05 level or less. 
receiving rye-vetch green manure. Tillage or surface mulch did not affect germination of sclerotia. Direct parasitism of sclerotia by Trichoderma spp. was not observed.

Soil physical and chemical factors. Soils in plots receiving CGT or rye-vetch had significantly higher levels of K (46.1 and $51.8 \mathrm{mg} / \mathrm{kg}$, respectively) than soil in plots amended with synthetic fertilizers or swine manure $(26.2$ and $29 \mathrm{mg} / \mathrm{kg}$, respectively) at the end of the second season. Other soil chemical factors did not differ significantly over the course of the experiment. Soils amended with CGT, swine manure, or rye-vetch retained a greater percentage of water at $\psi_{\mathrm{m}}$ values of 0 and $-1.0 \mathrm{KPa}$ than soils amended with synthetic fertilizers (Fig. 7). Soils amended with CGT also retained a greater percentage of soil water at drier $\psi_{\mathrm{m}}$ values, in the range of -2.5 to $-5.0 \mathrm{KPa}$, than soils in the other plots (Fig. 7). Soil bulk densities were highest in plots amended with synthetic fertilizers $\left(0.843 \mathrm{~g} / \mathrm{cm}^{3}\right)$ and lowest in plots amended with CGT $\left(0.738 \mathrm{~g} / \mathrm{cm}^{3}\right)$ at the end of the second year.

\section{DISCUSSION}

Organic soil fertility amendments significantly reduced the incidence of southern blight in processing tomato in both years in our study in contrast with conventional synthetic fertilizers. Disease incidence was higher in plots amended with synthetic fertilizers than in plots amended with organic fertility amendments. CGT was highly suppressive to disease in both years of the study. Cotton is produced in many areas in the southeast. Composting of the CGT is conducted at some but not all ginning facilities. This material is considered a nonvalue-added agricultural waste and was made available free of charge by the ginning facility. Our data indicate that this material is highly suppressive to southern blight
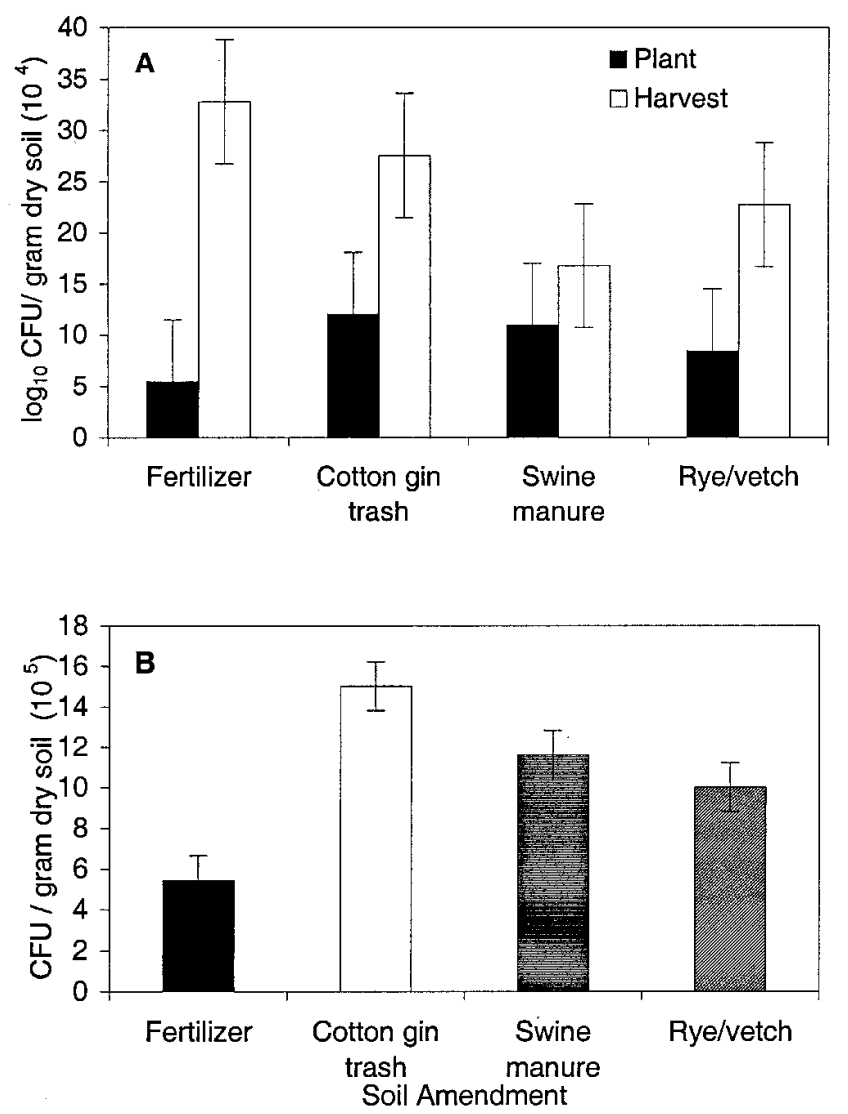

Fig. 3. Propagule densities of fluorescent Pseudomonas spp. as affected by A, soil amendments and sampling time in 1997 or by $\mathbf{B}$, soil amendment in 1998 (least significant difference $=6.1 \times 10^{4}$ and $1.21 \times 10^{5} \mathrm{CFU} / \mathrm{g}$ of soil in 1997 and 1998, respectively). and could be used as an alternative to or in combination with conventional soil fumigation or fungicides for disease control in problem areas of fields.

Some of the CGT used in our study may have contained genetically modified Bt cotton. However, less than $10 \%$ of the cotton fields were planted to Bt prior to the 2000 growing season; thereafter, acreage increased to $50 \%$ of the fields planted in North Carolina. Further studies are needed to determine the impact of cultivar-specific CGT types and specific chemical components of the CGT on sclerotia germination and disease suppression, because it is unclear whether a chemical or biological component of the CGT was active in disease suppression.

Yields varied greatly between years in our study. In 1997, when levels of rainfall were more optimal, highest yields occurred in plots with surface straw mulch and synthetic fertilizer, CGT, or swine manure. In the lower rainfall year in 1998, yields were low in all plots, regardless of soil amendment. In both years, plants in plots amended with a rye-vetch green manure had significantly lower yields than plants in plots with other amendments, regardless of tillage practice. The decomposing rye-vetch residues may have affected plant-available nitrogen in the soil, but further work is needed to confirm this hypothesis. Tomato yield dropped sharply from 1997 to 1998, and drought stress could have been important in 1998. When tomato plants are water stressed, by either too much water from irrigation or rain or too little water, plants can become more susceptible to soilborne pathogens (35-37). Water stress from too little water may have led to increased incidence of southern blight in 1998 in our study by either predisposing plants to more infection or stimulating sclerotia germination (34).

It is important to note that our yield data from 1997 indicate that, even in the first year of use of organic soil fertility amend-
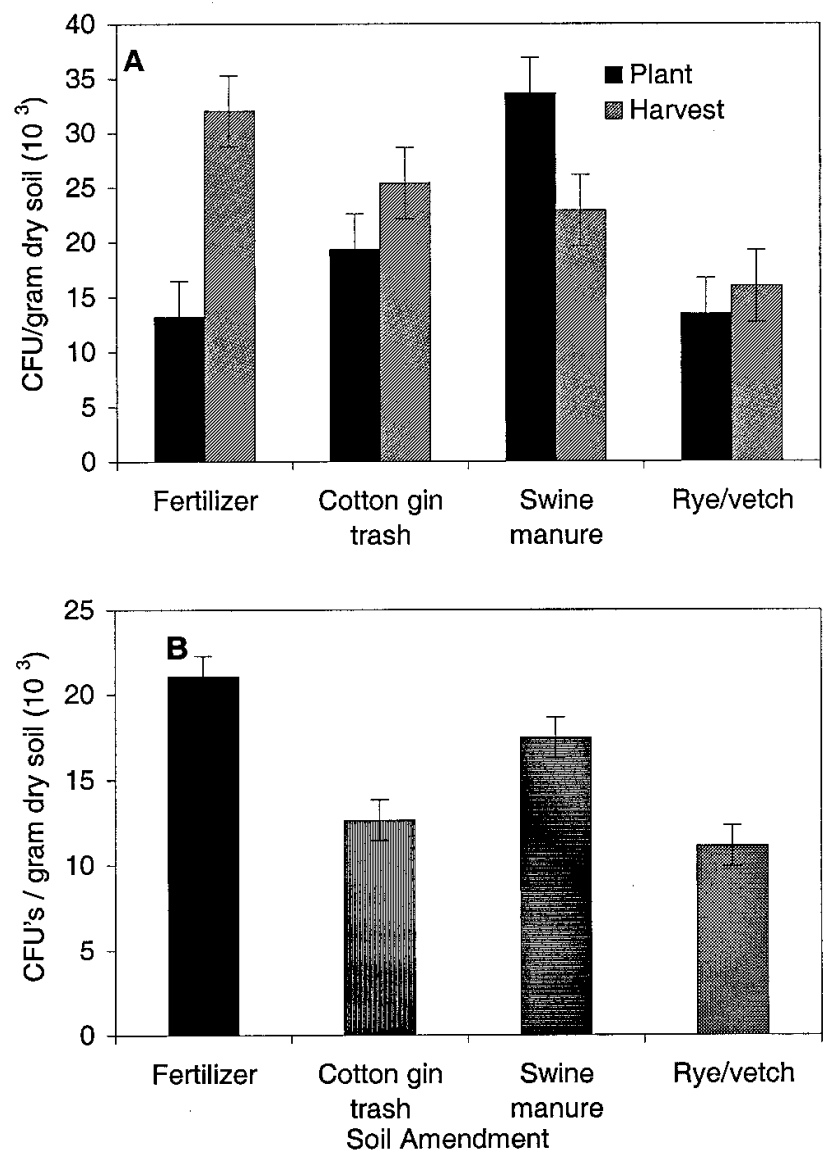

Fig. 4. Propagule densities of Fusarium spp. as affected by A, soil amendment and sampling time in 1997 or by $\mathbf{B}$, soil amendment in 1998 (least significant difference $=3.26 \times 10^{3}$ and $1.20 \times 10^{3} \mathrm{CFU} / \mathrm{g}$ of soil in 1997 and 1998). Note difference in $x$-axis scale. 
ments, yield was not compromised. Others have demonstrated that tomato harvest in conventional production systems were at least a week behind harvest in organic systems (43). However, labor costs associated with organic production can significantly lower the profit margin of an organic system (43). Comprehensive surveys of organic and conventional farms in California indicate little yield difference between conventional and organic growers (14). A 15 -year study at the Rodale Institute indicated that organic production systems not only produced yields of similar quantities, but more carbon and nitrogen was sequestered as organic matter in soil, possibly increasing the sustainability of the agroecosystem, regardless of organic amendment type (15).

Propagule densities of Trichoderma spp. were higher in soils amended with CGT or swine manure than in soils containing synthetic fertilizers or rye-vetch in our study. These organisms are known biocontrol agents of $S$. rolfsii and other pathogens (1,30, 33). Mycoparasitism of sclerotia of $S$. rolfsii has been observed and characterized previously (4). Trichoderma spp. have been formulated into commercially available biocontrol formulations for diseases caused by $S$. rolfsii. Our data indicate that sclerotia germination was reduced in soils with organic amendments to a greater extent than in soils with synthetic fertilizers. Antagonistic soil fungi may have contributed to reduced disease in our study by either direct parasitism of sclerotia, competition, or antibiosis; however, the actual mechanism of disease suppression was not elucidated in our study.

In our research plots, tomato planted in tilled bare soils had higher disease incidence than tomato planted in tilled surfacemulched soils with the same amendment. Disease incidence in the experimental plots was reduced by $50 \%$ by surface mulching plots
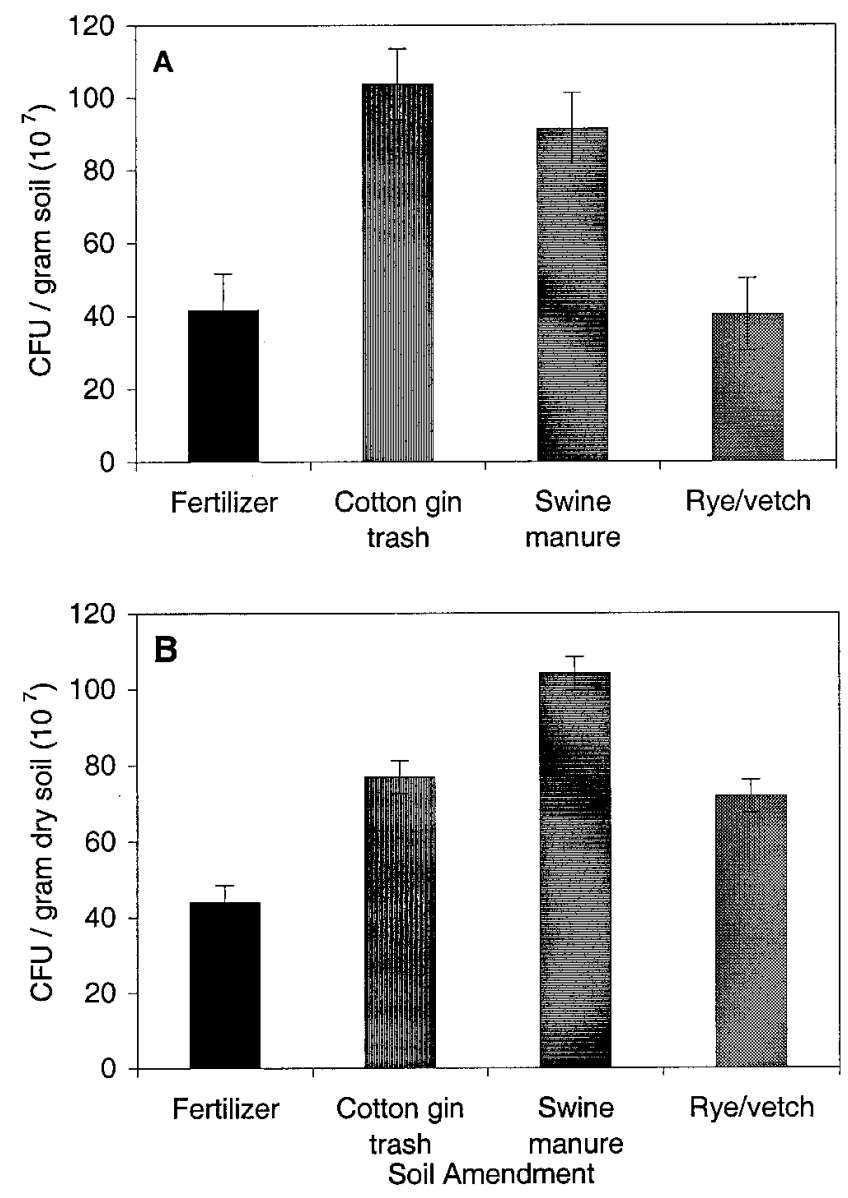

Fig. 5. Propagule densities of culturable bacteria as affected by organic and synthetic soil amendments in A, 1997 or B, in 1998 (least significant difference $=9.91 \times 10^{7}$ and $4.35 \times 10^{7} \mathrm{CFU} / \mathrm{g}$ of soil in 1997 and 1998, respectively). amended with synthetic fertilizer with wheat straw in 1997. Others have also shown that cultural practices can reduce the incidence of southern blight $(6,18,32)$. Black plastic and nylon mulch can limit the incidence of southern blight by providing a physical barrier that prevents pathogen and host contact (6). Layby cultivation, which brings soil containing sclerotia to the surface, resulted in increased disease incidence in carrots, whereas nonlayby cultivation and deep plowing suppressed southern blight (18). In our study in the first year, tillage may have brought inoculum to the soil surface where it was more likely to contact the host. Surface mulch may have acted as a physical barrier separating sclerotia from aboveground plant parts. While both surface-mulched and bare-soil plots were tilled once at the beginning of each season, monthly tillage in bare-soil plots in-
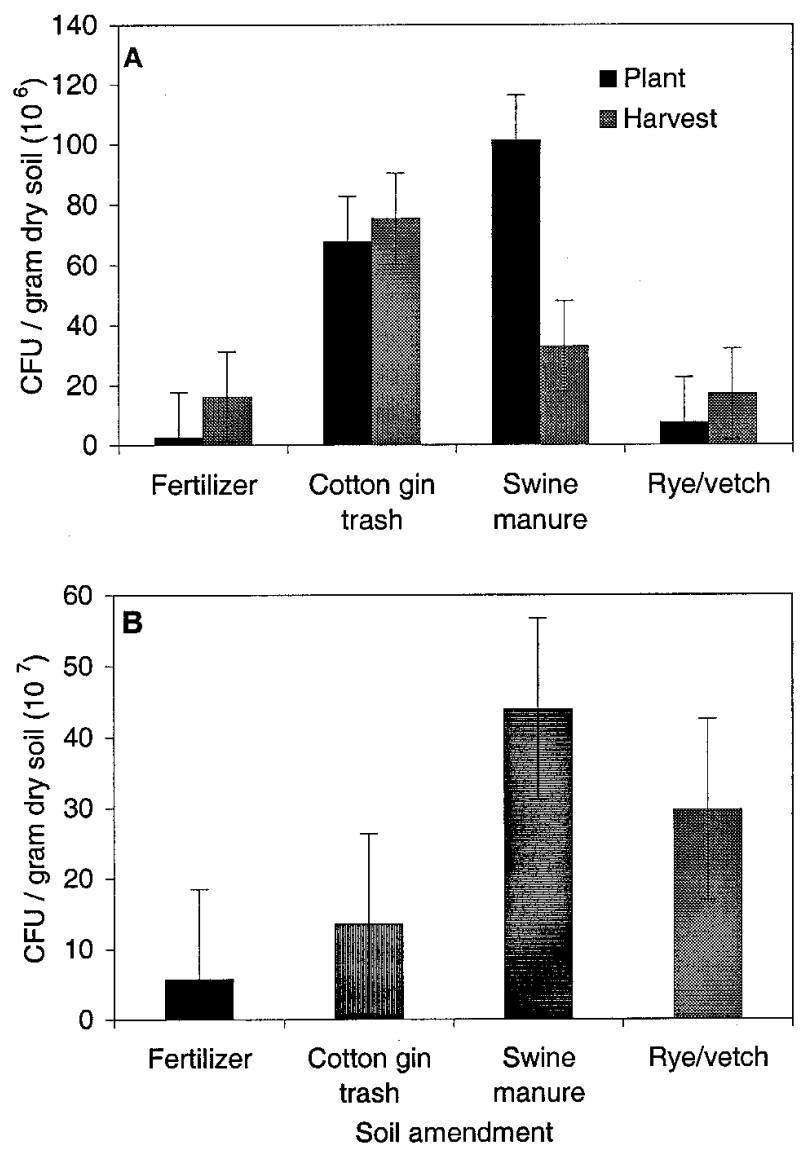

Fig. 6. Propagule densities of enteric bacteria as affected by A, soil amendment and sample time in 1997 or by $\mathbf{B}$, soil amendment in 1998 (least significant difference $=15.09 \times 10^{6}$ and $12.81 \times 10^{7} \mathrm{CFU} / \mathrm{g}$ of soil). Note difference in $x$-axis scale.

TABLE 6. Effect of organic and synthetic fertility amendments on the germination of sclerotia of Sclerotium rolfsii buried in soil at the Horticultural Crops Research Station in 1998

\begin{tabular}{lccc}
\hline & \multicolumn{3}{c}{ Germination (\%) } \\
\cline { 2 - 4 } Amendment & 0 weeks & 2 weeks & 4 weeks \\
\hline Synthetic fertilizer & 93.5 & 98.0 & 107.0 \\
Composted cotton-gin trash & 76.5 & 71.0 & 60.5 \\
Swine manure & 88.0 & 81.5 & 70.5 \\
Rye vetch green manure & 84.5 & 85.5 & 82.5 \\
Amendment effect $-P$ value & 0.019 & 0.002 & $<0.001$ \\
LSD $^{\mathrm{b}}$ & 14.92 & 17.45 & 22.43 \\
\hline
\end{tabular}

a Probabilities greater than $F$ from split-plot analysis of variance using Proc Mixed in SAS 8.0 (SAS Institute, Cary, NC).

${ }^{b}$ Least significant difference derived from the $95 \%$ confidence limits (Proc Mixed SAS 8.0, SAS Institute, Cary, NC). 
creased the likelihood that plant parts contacted sclerotia. Tillage can also affect the composition of soil microbial communities. Fungal communities tend to predominate in no-till and surfacemulched systems, as shifts from bacterial-based to fungal-based food webs occur in soil (3).

In our study, populations of total culturable bacteria, fluorescent pseudomonads, and enteric bacteria were higher in soils receiving organic amendments in both years than in soils with synthetic fertilizers. Drinkwater et al. demonstrated that soil from farms using organic production practices had higher populations of actinomycetes than soils from farms using conventional production practices (14). Organic amendments contain a complex of microorganisms, plants, and micro-, meso-, and macrofauna $(1,3,4,10)$. Fluorescent pseudomonads are known to induce host growth promotion and are also known biocontrol organisms for a number of soilborne pathogens. It was beyond the scope of our study to determine the individual components of the soil microbial community responsible for disease suppression.

Populations of enteric bacteria were higher at planting in soils amended with raw swine manure biosolids than in soils containing other soil fertility amendments. Enteric bacteria are best suited to life within the intestinal gut, with an abundant food supply and constant temperature; and, although these bacteria can survive in soil and water, they do not thrive in these substrates (5). The presence of large numbers of enteric bacteria in soils amended with raw swine manure after planting was expected. However, in 1997 after 75 days, the numbers of enteric bacteria associated with soil amended with swine manure was not different from soil containing synthetic fertilizers. Increases in numbers of bacterivorous nematodes were found in these plots, which may explain the decline in bacterial numbers over time (7). In 1998, propagule densities of enteric bacteria remained higher in soils amended with swine manure than other soil amendments over time. In contrast, others have found that populations of Escherichia coli (strain W3110) introduced into soil and water are not detectable after as little as 6 days (5). The swine manure biosolids used in our study would not be allowed in certified organic production systems because they were not composted. Composted animal manures are currently being used in these plots and would have been preferable for soil amendment in our study for numerous reasons, including reduction of potential pathogenic microorganisms on fruit and organic sequestration of leachable nutrients (15).

The use of organic amendments for soil fertility and to control soilborne plant disease could provide several advantages to growers.

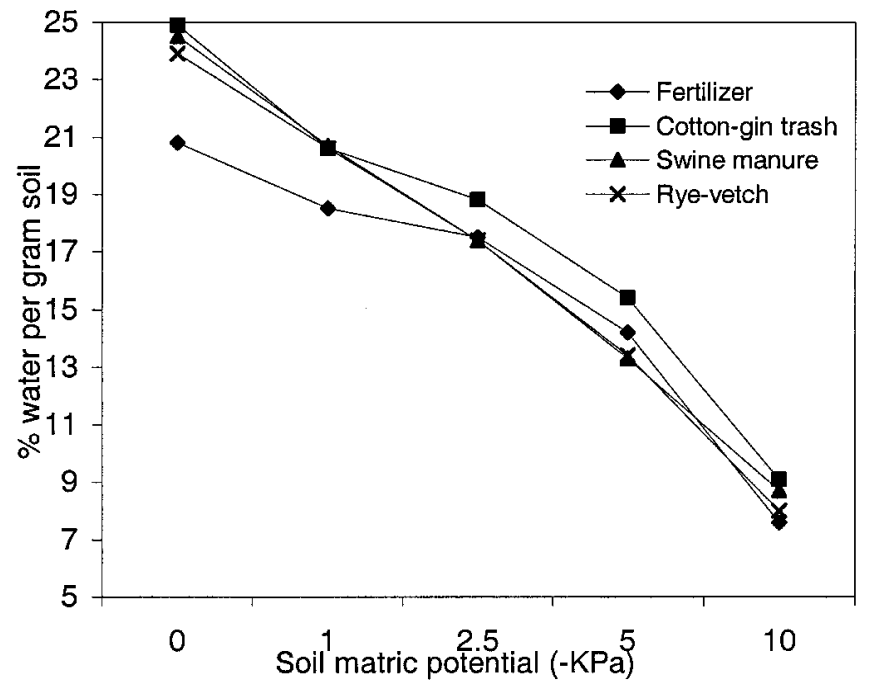

Fig. 7. Effect of soil amendment on the water holding capacity of an Orangeburg sandy loam soil at the Horticultural Crops Research Station. Soil was sampled after second season of soil amendments in 1999.
First, the cost of purchase of off-farm inputs may be reduced if local sources of organic amendments are grown and used, because transportation is the greatest expense associated with this type of fertilization. Second, the need for pesticides for plant disease control may be reduced, thus providing both an economic and environmental benefit. Third, organically produced commodities can be sold at a premium. Use of organic amendments may provide a use for valuable underutilized agricultural byproducts and improve the quality of the soil.

\section{ACKNOWLEDGMENTS}

This research was made possible through a grant from the USDA, CSREES, Sustainable Agriculture Research and Education Program (CR 4731-434 986) and from funds from the North Carolina State University Animal and Poultry Waste Management Center. We thank the thesis committee of L. R. Bulluck, including K. R. Barker and F. J. Louws of the Department of Plant Pathology and M. E. Barbercheck of the Department of Entomology; soil scientist G. Evanylo of Virginia Polytechnic Institute; agricultural research specialist G. Parra, Department of Plant Pathology; N. Creamer, Department of Horticulture; P. Puryear, Tobacco Literature Service; and M. L. Gumpertz, Department of Statistics, for technical and statistical advice.

\section{LITERATURE CITED}

1. Abada, K. A. 1994. Fungi causing damping-off and root-rot on sugarbeet and their biological control with Trichoderma harzianum. Agric. Ecosyst. Environ. 51:333-337.

2. Aycock, R. 1966. Stem rot and other diseases caused by Sclerotium rolfsii. N.C. Agric. Exp. Stn. Tech. Bull. 174.

3. Beare, M. H., Parmelee, R. W., Hendrix, P. F., Cheng, W., Coleman, D. C., and Crossley, J. D. A. 1992. Microbial and faunal interactions and effects on litter nitrogen and decomposition in agroecosystems. Ecol. Monogr. 62:569-591.

4. Benhamou, N., and Chet, I. 1996. Parasitism of sclerotia of Sclerotium rolfsii by Trichoderma harzianum: Ultrastructural and cytochemical aspects of the interaction. Phytopathology 86:405-416.

5. Bogosian, G., Sammons, L. E., Morris, P. J. L., O’Neil, J. P., Heitkamp, M. A., and Weber, D. B. 1996. Death of Escherichia coli K-12 strain w3110 in soil and water. Appl. Environ. Microbiol. 62:4114-4120.

6. Brown, J. E., Stevens, C., Osborn, M. C., and Bryce, H. M. 1989. Black plastic mulch and spunbonded row cover as method of southern blight control in pepper. Plant Dis. 73:931-932.

7. Bulluck, L. R., III. 2000. Effects of synthetic and organic soil amendments on soil biological communities, chemical and physical factors, and vegetable production, in Department of Plant Pathology. North Carolina State University, Raleigh, NC.

8. Bulluck, L. R., and Ristaino, J. B. 1998. Effects of organic and synthetic fertility amendments on southern blight, soil biological communities, and yield of processing tomatoes. (Abstr.) Phytopathology 88(suppl.): S12.

9. Burkholder, J. M., Mallin, M. A., Glasgow, H. B., Larsen, L. M., McIver, M. R., Shank, G. C., Deamer-Melia, N., Briley, D. S., Springer, J., Touchette, B. W., and Hanon, E. K. 1997. Impacts to a coastal river and estuary from rupture of a large swine waste holding lagoon. J. Environ. Qual. 26:1451-1466.

10. Canullo, G. H., Rodríguez-Kabana, R., and Kloepper, J. W. 1992. Changes in the populations of microorganisms associated with the application of soil amendments to control Sclerotium rolfsii. Plant Soil 144: 59-66.

11. Difco. 1984. Difco Manual-Dehydrated Culture Media and Reagents for Microbiology. 10th ed. Difco Laboratories, Detroit, MI.

12. Donohue, S. J., and Friedericks, J. B. 1984. Laboratory procedures. Page 47 in: Virginia Coop Ext. Serv. Vol. Publ. VPI\&SU, Blacksburg, VA.

13. Doran, J. 1995. Building soil quality. Pages 151-158 in: The 1995 Conservation Workshop on 'Opportunities and Challenges in Sustainable Agriculture'. Alberta Conservation Tillage Society and Alberta Agriculture Conservation, and Development Branch, Red Deer, Alberta, Canada.

14. Drinkwater, L. E., Letourneau, D. K., Workneh, F., van Bruggen, A. H. C., and Shennan, C. 1995. Fundamental differences between conventional and organic tomato agroecosystems in California. Ecol. Appl. 5:1098-1112.

15. Drinkwater, L. E., Wagoner, P., and Sarrantonio, M. 1998. Legume-based cropping systems have reduced carbon and nitrogen losses. Nature 396: 262-265.

16. Duniway, J. M. 1976. Movement of zoospores of Phytophthora 
cryptogea in soils of various textures and matric potentials. Phytopathology 66:877-882.

17. Elad, Y., Barak, R., and Chet, I. 1984. Parasitism of sclerotia of Sclerotium rolfsii by Trichoderma harzianum. Soil Biol. Biochem. 16: 381-386.

18. Gurkin, R. S., and Jenkins, S. F. 1985. Influence of cultural practices, fungicides, and inoculum placement on southern blight, and Rhizoctonia crown rot of carrot. Plant Dis. 69:477-481.

19. Gorodicki, B., and Hadar, Y. 1990. Suppression of Rhizoctonia solani and Sclerotium rolfsii diseases in container media containing composted separated cattle manure and composted grape marc. Crop Prot. 9:271274.

20. Hadar, Y., and Gorodecki, B. 1991. Suppression of germination of sclerotia of S. rolfsii in compost. Soil Biol. Biochem. 23:303-306.

21. Hoitink, H. A. J., and Boehn, M. J. 1999. Biocontrol within the context of soil microbial communities: A substrate dependent phenomenon. Annu. Rev. Phytopathol. 37:427-446.

22. Kundu, P. K., and Nandi, B. 1985. Control of Rhizoctonia disease of cauliflower by competitive inhibition of the pathogen using organic amendments in soil. Plant Soil 83:357-362.

23. Mallin, M. A., Burkholder, J. M., McIver, M. R., Shanks, G. C., Glasgow, H. B., Touchette, B. W., and Springer, J. 1997. Comparative effects of poultry and swine waste lagoon spills on the quality of receiving streamwaters. J. Environ. Qual. 26:1622-1631.

24. Masago, H., Yoshikawa, M., Fukada, M., and Nakanishi, N. 1977. Selective inhibition of Pythium spp. on a medium for direct isolation of Phytophthora spp. from soils and plants. Phytopathology 67:425428.

25. Mukherjee, P. K., and Raghu, K. 1997. Effect of temperature on antagonistic and biocontrol potential of Trichoderma sp. on Sclerotium rolfsii. Mycopathologia 139:151-155.

26. Munnecke, D. E., Kolbezen, M. J., and Bricker, J. L. 1982. Effects of moisture, chloropicrin, and methyl bromide singly and in mixtures on sclerotia of Sclerotium rolfsii and Verticillium albo-atrum. Phytopathology 72:1235-1238.

27. Mutitu, E. W., Mukunya, D. M., and Keya, S. O. 1988. Biological control of Fusarium yellows by Fusarium oxysporum Schl. f. sp. phaseoli Kendrick \& Snyder using organic amendments locally available in Kenya. Acta Hortic. 218:267-274.

28. Newhouse, J. R., and Hunter, B. B. 1980. The utilization of selective agar media in conjunction with baiting and root isolations of Cylindrocladium and Fusarium. (Abstr) Phytopathology 70:691

29. Papavizas, G. C., and Collins, D. J. 1990. Influence of Gliocladium virens on germination and infectivity of sclerotia of Sclerotium rolfsii. Phytopathology 80:627-630.

30. Papavizas, G. C., and Lewis, J. A. 1989. Effect of Gliocladium and Trichoderma on damping-off and blight of snapbean caused by
Sclerotium rolfsii in the greenhouse. Plant Pathol. 38:277-286.

31. Papavizas, G. C., and Lumsden, R. D. 1982. Improved medium for isolation of Trichoderma spp. from soil. Plant Dis. 66:1019-1020.

32. Punja, Z. K., Carter, J. D., Campbell, G. M., and Rossell, E. L. 1986. Effects of calcium and nitrogen fertilizers, fungicides, and tillage practices on incidence of Sclerotium rolfsii on processing carrots. Plant Dis. 70:819-824.

33. Punja, Z. K., Grogan, R. G., and Unruh, T. 1982. Comparative control of Sclerotium rolfsii on golf greens in northern California with fungicides, inorganic salts, and Trichoderma spp. Plant Dis. 66:1125-1128.

34. Punja, Z. K., and Jenkins, S. F. 1984. Influence of temperature, moisture, modified gaseous atmosphere, and depth in soil on eruptive sclerotial germination of Sclerotium rolfsii. Phytopathology 74:749-754.

35. Ristaino, J. B., and Duniway, J. M. 1989. Effect of preinoculation and postinoculation water stress on the severity of Phytophthora root rot in processing tomatoes. Plant Dis. 73:349-352.

36. Ristaino, J. B., Duniway, J. M., and Marois, J. J. 1988. Influence of frequency and duration of furrow irrigation on the development of Phytophthora root rot and yield in processing tomatoes. Phytopathology 78:1701-1706

37. Ristaino, J. B., Duniway, J. M., and Marios, J. J. 1989. Phytophthora root rot and irrigation schedule influence growth and phenology of processing tomatoes. J. Am. Soc. Hortic. Sci. 114:556-561.

38. Ristaino, J. B., Perry, K. B., and Lumsden, R. D. 1991. Effect of solarization and Gliocladium virens on sclerotia of Sclerotium rolfsii, soil microbiota, and incidence of southern blight on tomato. Phytopathology 81:1117-1124.

39. Ristaino, J. B., Perry, K. B., and Lumsden, R. D. 1996. Soil solarization and Gliocladium virens reduce the incidence of southern blight (Sclerotium rolfsii) in bell pepper in the field. Biol. Sci. Technol. 6:583-593.

40. Rodríguez-Kabana, R., Beute, M. K., and Backman, P. A. 1980. A method for estimating numbers of viable sclerotia of Sclerotium rolfsii in soil. Phytopathology 70:917-919.

41. Sands, D. C., and Rovira, A. D. 1970. Isolation of fluorescent pseudomonads with a selective medium. Appl. Microbiol. 20:513-514.

42. Shew, B. B., Wynne, J. C., and Beute, M. K. 1987. Field, microplot, and greenhouse evaluations of resistance to Sclerotium rolfsii in peanut. Plant Dis. 71:188-191.

43. Steffen, K. L., Dann, M. S., Harper, J. K., Fleischer, S. J., Mkhize, S. S., Grenoble, D. W., MacNab, A. A., Fager, K., and Russo, J. M. 1995. Evaluation of the initial season for implementation of four tomato production systems. J. Am. Soc. Hortic. Sci. 120:148-156.

44. Stevens, R. 1974. Mycology Guidebook. University of Washington Press, Seattle.

45. You, M. P., Sivasithamparam, K., and Kurtböke, D. I. 1996. Actinomycetes in organic mulch used in avocado plantations and their ability to suppress Phytophthora cinnamomi. Biol. Fertil. Soils 22:237-242. 